\title{
Ocena dostępności dawców koncentratów krwinek płytkowych o oznaczonych antygenach leukocytarnych i płytkowych dla pacjentów z przeciwciałami anty-HLA i/lub anty-HPA
}

\author{
Availability of the platelet concentrates for immunized patients \\ from donors with HLA and/or HPA typed antigens
}

\author{
Katarzyna Guzœ, Patrycja Łopacz, Agnieszka Gierszon®, Agnieszka Orzińska๑, \\ Małgorzata Uhrynowska@, Krystyna Maślanka, Ewa Brojer
}

Zakład Immunologii Hematologicznej i Transfuzjologicznej Instytutu Hematologii i Transfuzjologii w Warszawie

\section{Streszczenie}

Wstęp. Skuteczność przetoczeń koncentratów krwinek plytkowych (KKP) u pacjentów uodpornionych antygenami HLA (Human Leukocyte Antigens) i/lub HPA (Human Platelet Antigens) mozna zwiększyć, stosujac KKP od dawców nieposiadajacych antygenów, do których pacjent wytworzyt przeciwciata anty-HLA i/lub anty-HPA. Szczególna grupe biorców KKP stanowia noworodki z alloimmunologiczna matoptytkowościa plodowo-noworodkowa (AIMPN), wynikajaca z niszczenia plytek dziecka przez matczyne przeciwciała skierowane do antygenów plytek (szczególnie HPA-1a), które matka tworzy z powodu konfliktu plytkowego. W krajach wysoko rozwinietych dla pacjentów zimmunizowanych dostepni sq dawcy o oznaczonych antygenach HLA $i$ HPA.

Cel. Celem pracy byta ocena zapotrzebowania i dostępności takich dawców w Polsce na podstawie wyników ankiety rozestanej do 23 Centrów Krwiodawstwa i Krwiolecznictwa (CKiK) oraz dodatkowych informacji ustnych uzyskanych z CKiK.

Wyniki. Wyniki uzyskane z 21 CKiK wykazaty, że:

1) zapotrzebowania na KKP od dawców z oznaczonymi antygenami HLA i/lub HPA zgtoszono do $7 / 21(33,3 \%)$ CKiK;

2) w skali catego kraju w ciagu 1,5 roku przygotowano: 1788 KKP dla pacjentów z przeciwciatami anty-HLA, $63 \mathrm{KKP}$ dla pacjentów $z$ anty-HPA, $58 \mathrm{KKP}$ dla pacjentów $z$ anty-HLA $i$ anty-HPA; dla noworodków z AIMPN przygotowano 35 KKP od dawców bez antygenu, do którego byty skierowane przeciwciata u matki i 176 KKP pochodzacych od dawców przypadkowych;

3) w 13/21 (61,9\%) CKiK dobór dawców KKP dla pacjentów zimmunizowanych odbywa sie gtównie na podstawie próby krzyżowej w teście limfocytotoksycznym (LCT);

4) rejestry dawców z oznaczonymi antygenami HLA klasy I zawieraja dane 12885 osób, u 417 z nich zbadano antygeny HPA;

5) $w$ skali kraju do przetoczeń dla pacjentów zimmunizowanych antygenami HPA dostęnych jest 133 dawców HPA-1a ujemnych, wyselekcjonowanych na podstawie badań 5872 dawców. 
Wnioski. W Polsce, w porównaniu z innymi krajami, liczba dawców z oznaczonymi antygenami HLA i/lub HPA dla pacjentów zimmunizowanych jest niewystarczajaca. Ponadto zapotrzebowanie na dawców z rejestru ciagle rośnie dzięki rozwojowi diagnostyki AIMPN wykonywanej nie tylko w Instytucie Hematologii i Transuzjologii (IHiT), ale takze w laboratoriach CKiK. Pion krwiodawstwa jest zobowiazany do zabezpieczenia dostęności dawców KKP przeznaczonych dla pacjentów uodpornionych.

Słowa kluczowe: przetaczanie KKP, pacjenci uodpornieni HLA i/lub HPA, metody doboru KKP dla pacjentów uodpornionych, rejestry dawców z oznaczonymi HLA i/lub HPA

J. Transf. Med. 2019; 12: 1-12

\section{Summary}

Background. Clinical efficacy of PC transfusions in patients immunized with Human Leukocyte Antigens (HLA) and/or Human Platelet Antigens (HPA) can be improved by relying on platelets from donors typed for HLA and/or HPA. A specific group of PC recipients are newborns with alloimmune thrombocytopenia (FNAIT) resulting from maternal alloimmunization during pregnancy against specific fetal platelet antigens HPA (especially HPA-1a) produced by the mother as a result of fetomaternal HPA incompatibility.

Aim. The study aim was to assess the demand and availability for HPA/HLA typed donors in Poland.

Results. Outcome of a survey distributed to 23 Polish blood transfusion centers (CKiK) supplemented by data acquired in direct contact (phone) revealed that:

1) demand for PCs from donors with HLA and/or HPA typed antigens was reported in 7/23 (33.3\%) CKiK;

2) over a 1.5 year period, 1788 PCs were prepared for patients with anti-HLA-antibodies, 63 PCs for patients with anti-HPA-antibodies and 58 PCs - for patients with anti-HLA and anti-HPA antibodies. FNAIT neonates were transfused with 35 PCs from register donors and 176 PCs from casual donors;

3) in 13/23 CKiK (61.9\%) PC selection for immunized patients was mainly based on crossmatching in LCT;

4) registers report of 12,885 donors typed for HLA Class I antigens including 417 donors typed for HPA;

5) nation-wide there are 133 HPA-1 a negative donors available for immunized patients; they were selected after typing of 5872 donors;

Conclusions. The number of HLA and/or HPA typed donors for immunized patients is insufficient as compared to other countries. Moreover, the demand for registered donors is steadily growing due to expension of FNAIT diagnostics currently performed at the Institute of Hematology and Transfusion Medicine (IHiT) but also in the laboratories of CKiK.

One of the responsibilities of the blood transfusion service is to provide PCs for immunized patients.

Key words: PC transfusion, HLA and/or HPA immunized patients, PC selection methods for immunized patients, HLA and/or HPA donor registers

J. Transf. Med. 2019; 12: 1-12

\section{Wstęp}

Koncentraty krwinek płytkowych (KKP) od dawców o oznaczonych antygenach HLA i HPA są stosowane $\mathrm{w}$ transfuzjologii do przetoczeń u pa- cjentów uodpornionych tymi antygenami w celu ograniczenia ryzyka niepożądanych reakcji poprzetoczeniowych, szczególnie o charakterze odczynów gorączkowych oraz podniesienia skuteczności przetoczeń [1-4]. 
Pierwsza grupa takich pacjentów to biorcy leczeni przetoczeniami KKP, u których obserwuje się odczyny gorączkowe po transfuzji i/lub oporność na przetoczone płytki. U części $z$ nich te niepożądane objawy mają podłoże immunologiczne. Obecność przeciwciał anty-HLA obserwuje się u około 50-80\% tych pacjentów, a obecność przeciwciał anty-HPA u około 10-20\%. U około 5\% pacjentów wykrywa się przeciwciała anty-HPA i anty-HLA. Tworzenie przeciwciał jest wynikiem poprzednich transfuzji, zwłaszcza składników krwi niepoddanych leukoredukcji, a także immunizacji w wyniku przebytej ciąży [5, 6]. Procedury doboru KKP do przetoczenia dla pacjentów $\mathrm{z}$ przeciwciałami anty-HLA i/lub anty-HPA są opisane w Obwieszczeniu Ministra Zdrowia z 11 września 2018 r. w sprawie wymagań dobrej praktyki pobierania krwi i jej sktadników, badania, preparatyki, przechowywania, wydawania i transportu dla jednostek organizacyjnych publicznej stuzby krwi oraz w literaturze [7-10].

Drugą szczególną grupą pacjentów, u których stosuje się dobrane antygenowo KKP, są płody i noworodki $z$ alloimmunologiczną małopłytkowością (AIMPN) wywołaną przez matczyne przeciwciała skierowane do obcych antygenowo płytek krwi płodu (HPA). AIMPN jest spowodowana najczęściej przez przeciwciała anty-HPA-1a (> 85\%), a w drugiej kolejności przez przeciwciała anty-HPA-5b (5-10\%). Obserwuje się też inne swoistości: anty-HPA-1b, -2b, -3a, -3b, -15a, -15b i pozostałe rzadko występujące anty-HPA-6bw - 29bw lub skierowane do antygenów prywatnych, a czasami także do antygenów HLA kl I [11, 12].

$\mathrm{W}$ celu leczenia AIMP/N i zapobiegania najpoważniejszemu powikłaniu, jakim jest wylew do ośrodkowego układu nerwowego, a także zapewniania skutecznego i bezpiecznego przetaczania składników krwi pacjentom uodpornionym, opornym na przetaczania, niezbędna jest dostępność dawców, których płytki nie zawierają antygenów HPA, które powodują alloimmunizację. Ze względu na wysoką częstość immunizacji antygenem HPA1a, najważniejsze jest dysponowanie płytkami bez antygenu HPA-1a (od dawców HPA-1a ujemnych, czyli o genotypie $H P A-1 b / b)$. Dla noworodków $z$ AIMN mogą być też potrzebne KKP od dawców HPA-5b ujemnych (o genotypie HPA-5a/a), a sporadycznie od dawców homozygotycznych w zakresie innych antygenów HPA (HPA-1a/a, -2a/a, $-2 b / b$, $-3 a / a,-3 b / b,-5 b / b,-15 a / a,-15 b / b)$ [13-17]. Przetoczenia płytek od dawców przypadkowych mogą nie być skuteczne $[18,19]$.

W modelu brytyjskim leczenia małopłytkowości noworodkowej wymagającej przetoczeń KKP wszystkim noworodkom $z$ głęboką małopłytkowością (PLT $<50 \times 10^{9}$ ), a nie tylko noworodkom urodzonym przez matki z przeciwciałami anty-HPA, przetacza się w pierwszej kolejności KKP od dawców o fenotypie HPA-1a ujemnym/ /HPA-5b ujemnym, czyli bez antygenów HPA $\mathrm{w}>90 \%$ powodujących AIMPN, jednocześnie wdrażając diagnostykę serologiczną i molekularną konfliktu płytkowego [20, 21]. Wiadomo, że około $30 \%$ przypadków głębokiej małopłytkowości, która u noworodków występuje z częstszością około $0,15 \%$, jest spowodowanych alloimmunizacją matczyno-płodową, najczęściej do antygenu HPA-1a [11, 22].

Rejestry dawców krwi o oznaczonych antygenach HLA i HPA są dostępne do przetoczeń dla pacjentów $z$ małopłytkowością $w$ różnych krajach. W niektórych $z$ nich, na przykład w Wielkiej Brytanii, preparaty KKP HPA-1a ujemne/ /HPA-5b ujemne dla noworodków $z$ podejrzewaną lub zdiagnozowaną AIMPN (z powodu przeciwciał anty-HPA-1a, -5b) są dostępne całą dobę. Dawcy dla noworodków są grupą szczególnie wyselekcjonowaną. Przy ich kwalifikacji uwzględnia się status CMV, wysokość miana izoaglutynin anty-A i anty-B i innych przeciwcial do krwinek czerwonych, a także obecność przeciwciał do antygenów HPA, HLA i HNA. Dawcy ci mają dwukrotnie oznaczony antygen HPA-1a oraz -5b, najlepiej dwiema różnymi metodami, w dwóch, niezależnie pobranych próbkach krwi [20].

Celem obecnego opracowania jest analiza aktualnego stanu zapotrzebowań i dostępności dawców KKP o oznaczonych antygenach HLA i HPA dla pacjentów $z$ przeciwciałami do tych antygenów oraz przedstawienie potencjalnych możliwości zwiększenia liczby takich dawców dla zabezpieczenia pacjentów w Polsce.

\section{Material i metody}

Analizy przeprowadzono na podstawie ankiety dotyczącej wyżej wymienionych zagadnień, przeprowadzonej w CKiK (dane z okresu 01.2015-07.2016) oraz zestawienia przygotowanego w IHiT, podsumowującego aktualny stan liczbowy dawców homozygotycznych pod względem klinicznie istotnych antygenów HPA (tzw. dawcy o ograniczonej dostępności), którzy są dostępni do przetoczeń (stan na grudzień 2018 r.).

Ankieta została rozesłana do $23 \mathrm{CKiK}$ w: Białymstoku, Bydgoszczy, Gdańsku, Kielcach, Kaliszu, Krakowie, Katowicach, Lublinie, Łodzi, Olsztynie, Opolu, Poznaniu, Radomiu, Raciborzu, 
Rzeszowie, Słupsku, Szczecinie, Wałbrzychu, Warszawie, Wrocławiu i Zielonej Górze oraz do Wojskowego CKiK i CKiK MSWiA w Warszawie. Dodatkowo z CKiK uczestniczących w badaniu uzyskano telefonicznie uzupełniające/korygujące dane.

\section{Wyniki}

Wypełnione ankiety otrzymano z 21 CKiK. W 13 ankietach z: Białegostoku, Bydgoszczy, Kielc, Kalisza, Krakowa, Katowic, Lublina, Łodzi, Olsztyna, Opola, Poznania, Warszawy i Wrocławia podano informacje o zapotrzebowaniu na KKP dla pacjenta uodpornionego, o posiadaniu rejestrów dawców z oznaczonymi antygenami HLA/HPA i wykonywanych badaniach fenotypu/genotypu tych antygenów. W ankietach $z 8$ pozostałych CKiK (z Gdańska, Radomia, Raciborza, Rzeszowa, Słupska, Szczecina, Wałbrzycha, Zielonej Góry) podano, że centra te nie posiadają rejestrów dawców $z$ oznaczonymi antygenami HLA/HPA oraz nie wykonują badań tych antygenów ani doboru dawców dla pacjentów zimmunizowanych. $Z$ terenu działalności tych Centrów nie zgłoszono żadnego zapotrzebowania na KKP dla pacjenta uodpornionego.

Analizę wyników ankiet $\mathrm{z}$ CKiK, w których zawarto odpowiedzi na postawione pytania (wszystkie lub niektóre), przedstawiono poniżej.

\section{Dostępność dawców o oznaczonych antygenach HLA i dobór dawców dla pacjentów uodpornionych}

Wyniki tej analizy przedstawiono w tabeli 1 . Ogólem liczba dawców z oznaczonymi antygenami HLA klasy I wynosiła na koniec 2016 roku 12885 osób, a 417 dawców miało oznaczone antygeny HLA i HPA.

Dobór dawców KKP dla pacjentów $z$ obecnymi przeciwciałami anty-HLA dokonywany jest w większości CKiK na podstawie prób krzyżowych w teście LCT (Białystok, Kalisz, Katowice, Kielce, Kraków, Lublin, Łódź, Poznań, Warszawa, Wrocław).

\section{Dawcy z oznaczonymi antygenami HPA}

Wyniki tej analizy przedstawiono w tabeli 2. Ogółem liczba dawców krwi, u których do końca 2016 roku oznaczono antygeny HPA, wynosiła 5872 osoby. Byli to dawcy z CKiK Katowice, Kielce, Lublin, Opole, Poznań, Radom, Warsza-

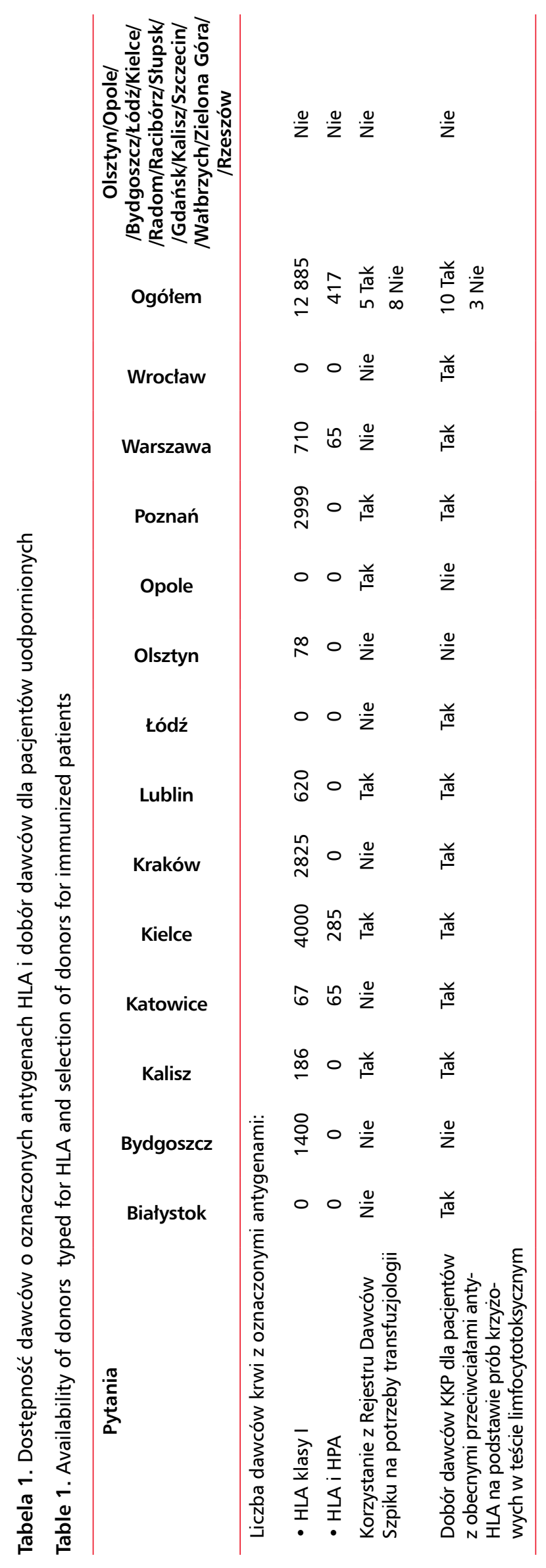


Tabela 2. Dawcy z oznaczonymi antygenami HPA

Table 2. Donors typed for HPA

\begin{tabular}{|c|c|c|c|c|c|c|c|c|c|}
\hline & \multicolumn{9}{|c|}{ CKiK - liczba dawców (w tym badanych z II pobrania) — stan na grudzień 2018 r. } \\
\hline & Warszawa & Kielce & Katowice & Lublin & Poznań & Wrocław & Radom & Opole & Ogółem \\
\hline Ogółem przebadanych & 2025 & 285 & 67 & 810 & 2159 & 378 & 49 & 99 & 5872 \\
\hline \multicolumn{10}{|l|}{ W tym zidentyfikowano } \\
\hline \multicolumn{10}{|c|}{ genotyp/fenotyp HPA o ograniczonej dostępności: } \\
\hline $\begin{array}{l}\text { HPA-1bb (HPA-1a } \\
\text { ujemny) }\end{array}$ & $40(35)$ & $13(3)$ & $4(4)$ & $25(6)$ & $35(23)$ & $11(9)$ & 0 & $5(1)$ & $133(81)$ \\
\hline $\begin{array}{l}\text { HPA-1bb 3aa } \\
\text { (HPA-1a, -3b ujemny) }\end{array}$ & $15(15)$ & $7(2)$ & $1(1)$ & 13 & $10(10)$ & $1(1)$ & & & $44(29)$ \\
\hline $\begin{array}{l}\text { HPA-1 bb 3bb } \\
\text { (HPA-1a, -3a ujemny) }\end{array}$ & $4(4)$ & 2 & 0 & 5 & $1(1)$ & $4(4)$ & & & $16(9)$ \\
\hline $\begin{array}{l}\text { HPA-2bb } \\
\text { (HPA-2a ujemny) }\end{array}$ & $2(2)$ & 1 & 0 & 2 & & & & & $5(2)$ \\
\hline $\begin{array}{l}\text { HPA-5bb } \\
\text { (HPA-5a ujemny) }\end{array}$ & $3(1)$ & $3(1)$ & 0 & $1(1)$ & & & & & $7(3)$ \\
\hline $\begin{array}{l}\text { HPA-1aa 2aa 3aa 5aa } \\
\text { (HPA-1b, 2b, 3b, 5b } \\
\text { ujemny) }\end{array}$ & $48(25)$ & 44 & 11 & 15 & & & & & $118(25)$ \\
\hline $\begin{array}{l}\text { HPA-1aa 2aa 3bb 5aa } \\
\text { (HPA-1b, 2b, 3a, 5b } \\
\text { ujemny) }\end{array}$ & $17(6)$ & 17 & 5 & 4 & & & & & $43(6)$ \\
\hline
\end{tabular}

wa, Wrocław. W tej grupie zidentyfikowano 133 dawców HPA-1a ujemnych. Oznaczenia antygenu HPA-1a prowadzono metodami serologicznymi: 1) metodą ELISA $z$ użyciem testu komercyjnego Platelet HPA 1a Typing Assay firmy DiaMed [23] lub 2) metodą FACS opartą na cytometrii przepływowej (wg protokołu dostarczonego przez IHiT) [24] albo technikami biologii molekularnej opartymi na PCR: 3) PCR-SSP według Skogena i wsp. [25] lub testem HPA Ready Gene (Inno-Train, Niemcy), 4) RQ-PCR według Fičko i wsp. [26]. Weryfikację dawców HPA-1a ujemnych $z$ drugiego pobrania $z$ poszerzeniem typowania o inne układy HPA w latach 2016-2018 wykonywano w IHiT testem HPA Fluo Gene (Inno-Train, Niemcy).

W grupie dawców HPA-1a ujemnych (HPA$1 b b)$ oraz u części dawców HPA-1a dodatnich wykonano badania innych antygenów (HPA-2, -3, -5) w celu identyfikacji homozygot w antygenach tych układów. Dzięki nim w rejestrze znajdują się też dawcy homozygotyczni dla pacjentów zimmunizowanych innymi antygenami niż antygen HPA-1a.

\section{Zamówienia KKP dla pacjentów zimmunizowanych $\mathrm{z}$ opornością na przetaczane plytki}

Wyniki tego zagadnienia przedstawiono $\mathrm{w}$ tabeli 3. W analizowanym okresie, zapotrzebowania na dawców o oznaczonych antygenach HLA lub/i HPA zgłoszono do 7 CKiK. Do pozostałych CKiK (14) takie zapotrzebowania nie były wystosowane. Ogółem w okresie 1,5 roku zamówiono dla pacjentów uodpornionych antygenami HLA lub/i HPA z opornością na przetaczane płytki, czyli $z$ niesatysfakcjonującym wskaźnikiem wzrostu płytek po przetoczeniu (PPR, percentage platelet recovery < 30\%) - 1961 KKP, w tym dla biorców z przeciwciałami: anty-HLA - $1788 \mathrm{KKP}$; anty-HPA $-63 \mathrm{KKP}$; anty-HLA i anty-HPA $-58 \mathrm{KKP}$.

\section{Zamówienia KKP na potrzeby przetoczeń dla płodów/noworodków z AIMP/N}

Wyniki tego zapotrzebowania przedstawiono w tabeli 4. Zamówienia na KKP dla płodów/noworodków z AIMPN otrzymały CKiK Lublin, Łódź, 


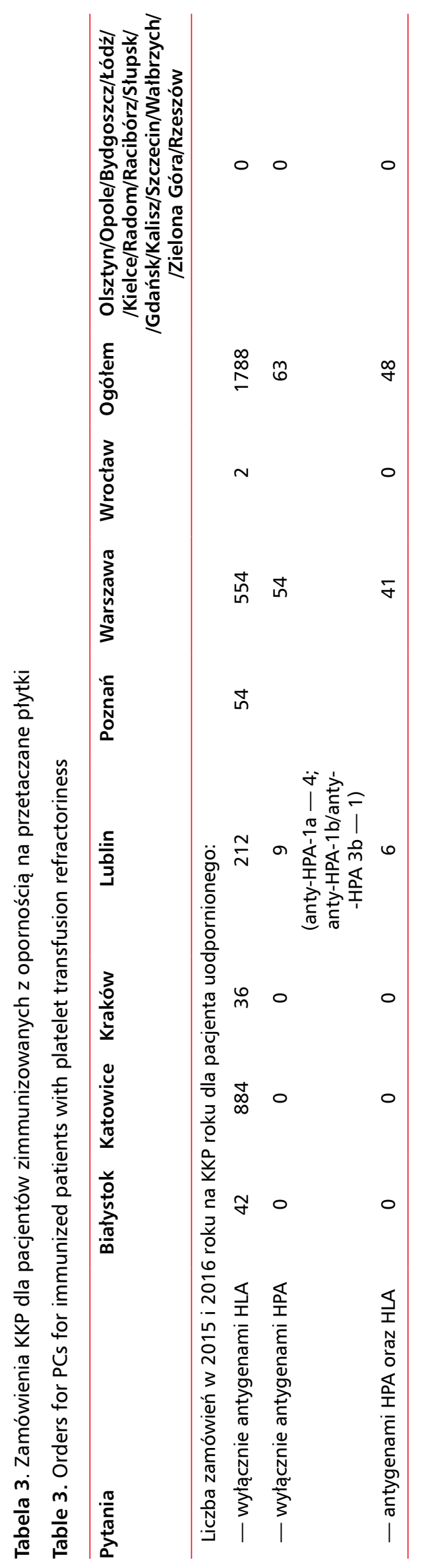

Poznań, Warszawa i Wrocław. Zamówiono ogólem 225 KKP: 14 KKP przygotowano od matki, a 211 KKP od dawcy, w tym jedynie 35 KKP od dawcy bez antygenu, do którego matka miała przeciwciała, a pozostałe $176 \mathrm{KKP}$ od dawców przypadkowych.

\section{Badania genotypu/fenotypu HLA i HPA}

Charakterystykę metod typowania HLA/HPA przedstawiono w tabeli 5. Oznaczenia fenotypu/ /genotypu antygenów HLA w ramach własnej pracowni prowadziło w badanym okresie 9 CKiK (Białystok, Kalisz, Katowice, Kielce, Kraków, Lublin, Olsztyn, Poznań, Warszawa), a w podmiotach zewnętrznych 2 CKiK (Lublin, Wrocław). Do oznaczania antygenów HLA stosowano metody serologiczne (7 CKiK: Białystok, Kalisz, Katowice, Kraków, Lublin, Warszawa, Wrocław) lub metody biologii molekularnej (6 CKiK: Białystok, Katowice, Kielce, Lublin, Olsztyn, Poznań). W programach zewnętrznej kontroli jakości metod oznaczania antygenów HLA uczestniczyło 9 CKiK (Białystok, Kalisz, Katowice, Kielce, Kraków, Lublin, Olsztyn, Poznań, Warszawa).

Oznaczenia fenotypu/genotypu antygenów HPA w ramach własnej pracowni przeprowadzily 3 CKiK (Lublin, Opole, Poznań), a dla 5 CKiK (Katowice, Kielce, Radom, Warszawa, Wrocław) badania te wykonał IHiT (nieodpłatnie). Były one finansowane ze środków pochodzących $z$ projektów badawczych z Komitetu Badań Naukowych lub Narodowego Centrum Badań i Rozwoju albo w ramach prac naukowo-rozwojowych, realizowanych ze środków własnych IHiT.

W 2 CKiK w latach 2007-2010 do badań stosowano test ELISA (Platelet HPA 1a Typing Assay, Diamed) do oznaczenia antygenu HPA-1a (Opole, Poznań). Czynnymi dawcami krwi jest wciąż 16 dawców HPA-1a ujemnych zidentyfikowanych $\mathrm{w}$ tym czasie (5 w Opolu, $11 \mathrm{w}$ Poznaniu).

W 2013 roku wdrożono w IHiT oznaczanie antygenu HPA-1a za pomocą metody opartej na cytometrii przepływowej (FACS) dla obsługi grantu PREVFNAIT p.t. „Zapobieganie alloimmunologicznej małopłytkowości płodów i noworodków (AIMPN) w Polsce”, finansowanego ze środków Programu Polsko-Norweska Współpraca Badawcza, prowadzonego przez Narodowe Centrum Badań i Rozwoju w ramach Norweskiego Mechanizmu Finansowego na lata 2009-2014 (umowa nr Pol-Nor/203111/69/2013) [11]. W 2016 roku IHiT wytypował tą metodą łącznie 1693 dawców z CKiK w Warszawie i Wrocławiu, a CKiK w Poznaniu rozpoczęło identyfikację dawców HPA-1a ujem- 
Tabela 4. Zamówienia KKP na potrzeby przetoczeń dla płodów/noworodków z AIMPN

Table 4. Orders for PCs for fetuses or FNAIT neonates

\begin{tabular}{|c|c|c|c|c|c|c|c|}
\hline $\begin{array}{l}\text { Liczba KKP przygo- } \\
\text { towywanych } \\
\text { w } 2015 \text { i } 2016 \text { roku } \\
\text { dla płodów/nowo- } \\
\text { rodków z AIMP/N }\end{array}$ & Warszawa & Poznań & Lublin & Łódź & Wrocław & $\begin{array}{c}\text { Białystok/Bydgoszcz/ } \\
\text { /Gdańsk/Kalisz/Katowice/ } \\
\text { /Kielce/Olsztyn/Opole/ } \\
\text { /Racibórz/Radom/Rzeszów/ } \\
\text { /Słupsk/Szczecin/Wałbrzych/ } \\
\text { /Zielona Góra }\end{array}$ & Ogółem \\
\hline Od matki & 0 & 13 & 0 & 1 & 0 & 0 & 14 \\
\hline $\begin{array}{l}\text { Od dawcy innego } \\
\text { niż matka }\end{array}$ & $\begin{array}{c}165, \\
\text { w tym } 30 \\
\text { od dawców } \\
\text { HPA-1bb } \\
\text { z rejestru; } \\
\text { pozostali } \\
\text { przypadkowi }\end{array}$ & $\begin{array}{c}41 \\
\text { od } \\
\text { dawców } \\
\text { przy- } \\
\text { padko- } \\
\text { wych }\end{array}$ & $\begin{array}{c}4 \\
\text { od } \\
\text { dawców } \\
\text { HPA-1bb }\end{array}$ & 0 & 1 & 0 & 211 \\
\hline
\end{tabular}

nych techniką FACS we własnym laboratorium, przysyłając krew 25 dawców HPA-1a ujemnych do IHiT na weryfikację genotypu HPA-1. Ogólem wytypowano wtedy 62 nowych dawców HPA-1a ujemnych (26 w Warszawie, 11 we Wrocławiu, $25 \mathrm{w}$ Poznaniu). W IHiT potwierdzono prawidłowość oznaczeń statusu HPA-1a metodą FACS i RQ-PCR w każdej z próbek. Centrum Krwiodawstwa i Krwiolecznictwa w Poznaniu w 2017 roku i w 2018 roku uczestniczyło w programie zewnętrznej kontroli jakości metod fenotypowania antygenu HPA-1a organizowanego przez IHiT.

Samodzielne badania genotypowania antygenów HPA prowadzi CKiK w Lublinie (testy PCR-SSP firmy Inno-Train). To CKiK uczestniczyło w 5 edycjach programu zewnętrznej kontroli jakości metod genetycznych oznaczania antygenów HPA zorganizowanego przez IHiT (2011, 2015-2018).

Genotypowanie antygenów HPA (m.in. u dawców krwi) metodami biologii molekularnej jest wykonywane w IHiT od 1995 roku. Początkowo była to metoda PCR-SSP typu „home made” [24], potem wprowadzono zwalidowaną metodę RQ-PCR „home made” [25], którą zastosowano do genotypowania dawców w ramach planów naukowych IHiT dla CKiK Warszawa, Katowice, Kielce, Radom, a metodę dla genotypowania HPA-1 stosowano te $\dot{z}$ w grancie PREVFNAIT i służy ona do weryfikowania wyników fenotypu HPA-1a ujemnego, czyli była wykorzystywana do weryfikacji fenotypu HPA-1a ujemnego u dawców z CKiK.

W IHiT są też używane testy komercyjne ze znakiem IVD oparte o PCR (PCR-SSP, RQ-PCR), za pomocą których dokonuje się weryfikacji rzadkich fenotypów/genotypów HPA $z$ drugiego pobrania i poszerza oznaczenia o inne układy antygenów HPA. Na koniec 2018 roku badania weryfikujące genotypy HPA $z$ drugiego pobrania objęły 81/133 dawców $H P A-1 b b$ (zidentyfikowano 29 dawców $H P A-1 b / b,-3 a / a$ oraz $9 H P A-1 b / b,-3 b / b)$ oraz $2 / 5$ dawców $H P A-2 b / b$ i 3/7 dawców $H P A-5 b / b$. Dane liczbowe zawiera tabela 2 .

Weryfikowanie antygenów HPA alternatywną metodą genetyczna/serologiczną jest istotne ze względu na konieczność wyeliminowania błędów technicznych metody, które mogą wynikać $z$ istnienia dodatkowych polimorfizmów w sekwencji genów kodujących antygeny HPA w miejscach przyłączania się starterów/sond lub wpływających na epitop antygenowy, co może być przyczyną nieprawidłowego fałszywie ujemnego wyniku typowania u osoby $z$ taką $z$ mutacją [27].

\section{Wyniki}

Zagadnienia doboru dawców do przetoczeń KKP dla pacjentów zimmunizowanych opornych na przetoczenia płytek oraz dla płodów/noworodków z AIMP/N jest włączone w działalność 13/21 CKiK, które udzieliły odpowiedzi na ankietę.

W celu doboru skutecznych klinicznie KKP dla pacjentów zimmunizowanych antygenami HLA opornych na przetoczenia płytek CKiK dysponują następującymi metodami: testem limfocytotoksycznym (LCT) dla doboru w próbie krzyżowej oraz doborem dawców zgodnych antygenowo $z$ rejestru dawców o oznaczonych antygenach HLA. Ogólna liczba dawców o oznaczonych antygenach HLA na koniec 2016 roku była wysoka i wynosiła 12 885. Część CKiK (5/12) wykorzystuje dla celów transfuzjologicznych rejestr dawców szpiku. Wobec aktywnego udziału CKiK w typowaniu antygenów HLA dla celów transplantologicznych, szczególnie $\mathrm{w}$ dobie obecnie stosowanej wysokoprzepustowej 


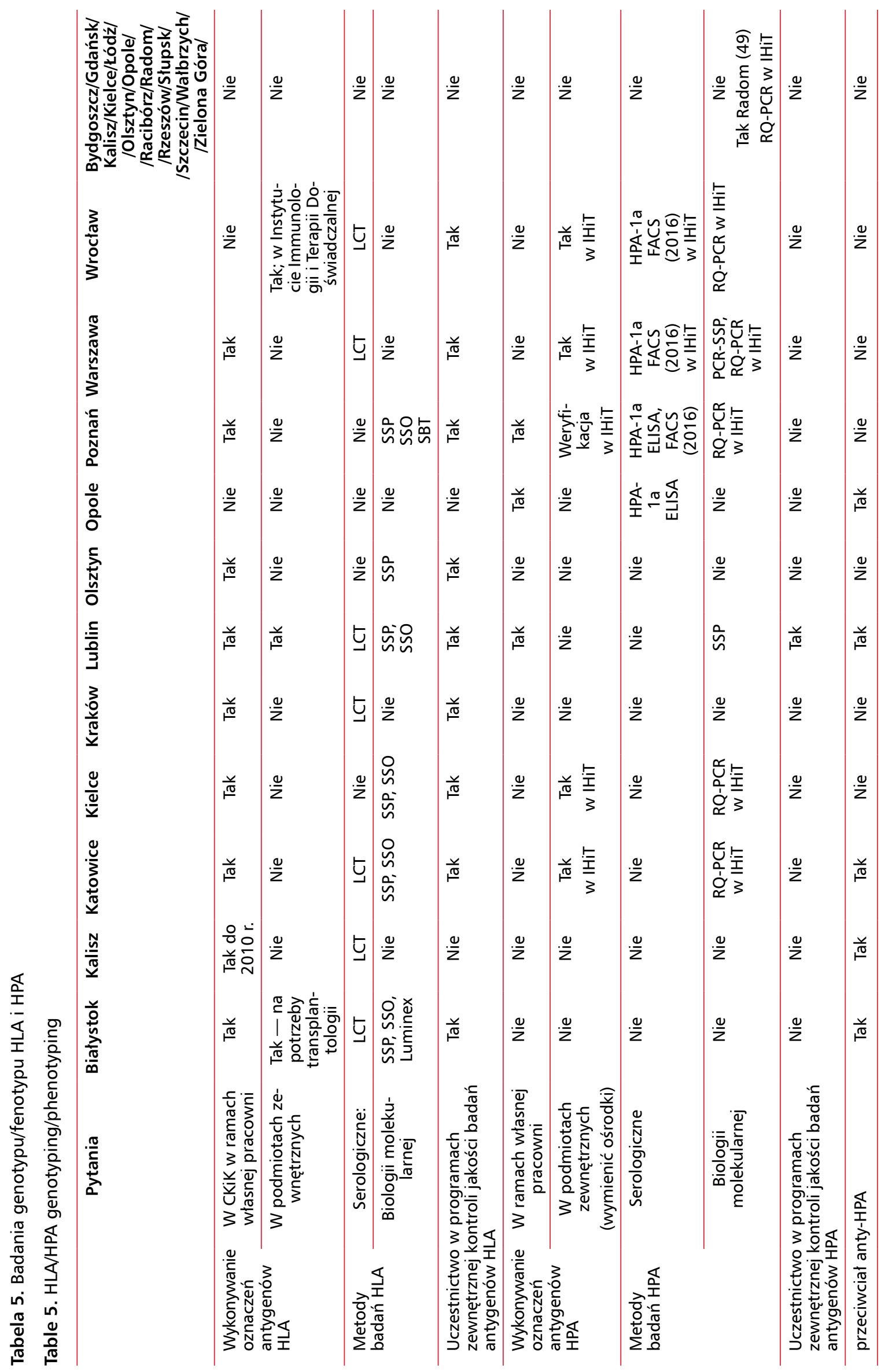


techniki sekwencjonowania następnej generacji (NGS) - istnieją duże, potencjalne możliwości rozszerzenia liczebności rejestru dawców o znanych antygenach HLA do przetoczeń płytek. Możliwości te należy aktywnie wykorzystywać, by zwiększając liczebność rejestrów dawców szpiku, móc powiększać zasób rejestrów dawców KKP $z$ oznaczonymi antygenami HLA klasy I, poprzez pozyskanie tych wyników $z$ zasobów rejestrów transplantologicznych. Należy w tym miejscu podkreślić, że próby krzyżowe w teście limfocytotoksycznym nie mogą być jedyną metodą doboru dawców dla biorców opornych na przetoczenia płytek. Dobór dawców o zgodnych antygenach HLA jest konieczny w przypadku obecności przeciwciał anty-HLA niezależnych od dopełniacza, a także w przypadkach, gdy próby krzyżowe w LCT $z$ limfocytami wszystkich lub większością dawców są dodatnie. Metodą doboru KKP dla takiego pacjenta są płytki o zgodnych lub krzyżowo reagujących antygenach HLA. Należy pamiętać, że KKP $z$ aferezy dobrany w HLA zwiększa skuteczność przetoczeń, bo zapobiega niszczeniu płytek przez przeciwciała chorego, a także ogranicza ekspozycję na inne antygeny, ale wiąże się $z$ większym ryzykiem wywołania poprzetoczeniowej choroby przeszczep przeciw biorcy (TA-GvHD, transfusion-associated graft-versus-host disease), czemu zapobiega stosowanie napromieniowanych KKP lub poddanych wybranym metodom inaktywacji [28].

Dla płodów oraz noworodków z AIMPN, powodowaną przez przeciwciała przeciwpłytkowe anty-HPA (głównie anty-HPA-1a lub anty-HPA-5b), należy dobierać KKP bez antygenu, do którego są skierowane przeciwciała matki. Jeśli to spodziewany przypadek AIMPN na podstawie diagnozy w poprzedniej ciąży bądź zidentyfikowany w trakcie ciąży z powodu podejrzenia wylewu do ośrodkowego układu nerwowego w badaniu USG i/lub wykrycia przeciwciał anty-HPA w badaniach przeglądowych (jak w PREVFNAIT), to przygotowanie ubogoleukocytarnego, napromieniowanego KKP można zaplanować na czas wykonania transfuzji dopłodowej lub planowanego porodu. Wymaga to ścisłej koordynacji pomiędzy szpitalem, w którym pacjentka jest objęta specjalistyczną opieką w czasie ciąży i gdzie zamierza urodzić, a lokalnym CKiK, który dostarczy UKKP. Dawcą UKKP zgodnego w HPA może być matka, o ile zostanie zakwalifikowana jako dawca krwi pełnej lub do trombaferezy, a ośrodek podejmie się pobrania krwi od kobiety w ciąży. $Z$ pozyskanego od matki koncentratu krwinek płytkowych należy usunąć osocze, ponieważ zawiera alloprzeciwciała, a płytki należy zawiesić w 5-procentowym roztworze albuminy lub osoczu dawcy grupy $\mathrm{AB}$ oraz obowiązkowo napromieniować. Powoduje to skrócenie okresu ważności KKP w odniesieniu do standardowego czasu przechowywania.

Planowane przygotowanie napromieniowanego UKKP dla użytku dopłodowego/pediatrycznego będzie logistycznie prostsze od dawców krwi z rejestru dawców o oznaczonych antygenach HPA. Dawcy dla noworodków muszą mieć dwukrotnie wykonane badania antygenów HPA, $z$ dwóch różnych pobrań. Dawcy do przetoczeń KKP powinni być zgodni z pacjentem w antygenach układu $\mathrm{ABO}$ $[3,4,7]$, ale ze względu na niedojrzałość wyrażania antygenów $\mathrm{ABO}$, u płodów/noworodków stosuje się zazwyczaj UKKP grupy O, dodatkowo grupy $\mathrm{RhD}$ ujemnej dla dziewczynek (zapobieganie immunizacji antygenem D $z$ niewielkiej ilości erytrocytów zanieczyszczających KKP). Dlatego warto zadbać o stałą dostępność KKP od dawców o fenotypie HPA-1a ujemnym/HPA-5b ujemnym grupy O RhD ujemnej i O RhD dodatniej, by wzorując się na procedurze stosowanej w Wielkiej Brytanii, każdemu noworodkowi z małopłytkowością przetaczać takie KKP do czasu wykluczenia, $\dot{z}$ e nie jest ona wynikiem alloimmunizacji tymi najbardziej immunogennymi antygenami HPA.

Ze względu na niską częstość fenotypu HPA1a ujemnego (2\%), dla utworzenia wystarczająco liczebnego rejestru dawców HPA-1a ujemnych, konieczne jest przeprowadzenie badań w dużej grupie dawców. Ogólna liczba dawców, u których do końca 2016 roku oznaczono antygeny HPA, wynosiła 5872. Badania nakierowano przede wszystkim na identyfikację dawców HPA-1a ujemnych. $Z$ tej grupy wyłoniono 133 dawców HPA-1a ujemnych $(2,3 \%)$, co jest zgodne $z$ oczekiwaniami. Dalsze badania były prowadzone u dawców HPA-1a ujemnych oraz u części dawców HPA-1a dodatnich w celu identyfikacji dawców o homozygotycznych genotypach HPA-1aa, HPA-2aa i -2bb, HPA- 3aa i $-3 b b$ oraz HPA-5aa i $-5 b b$. Tacy dawcy są potrzebni dla pacjentów uodpornionych innymi antygenami płytek niż antygen HPA-1a. W wyniku tych badań zidentyfikowano od kilku do kilkudziesięciu dawców dostępnych do przetoczeń, w zależności od antygenu.

W ankiecie przesłanej do CKiK zadano także pytania dotyczące zapotrzebowania na KKP dla pacjentów zimmunizowanych antygenami HLA i HPA. Nadesłane wyniki wskazują, że liczba zapotrzebowań na KKP dla biorców zimmunizowanych antygenami HLA w skali całego kraju na przestrzeni 1,5 roku wynosiła 1788 (najwięcej w Katowicach, 
Lublinie i Warszawie). KKP dla pacjentów zimmunizowanych CKiK dobierają na podstawie próby zgodności w teście limfocytotoksycznym, co jest zgodne $z$ rekomendacjami zawartymi w światowej literaturze. Mają też możliwość doboru dawców zgodnych w antygenach HLA. Okazjonalnie CKiK w Lublinie i w Warszawie otrzymywały zapotrzebowania na dobór dawców o zgodnych antygenach HLA i HPA lub tylko HPA.

Zapotrzebowania na KKP dla noworodków z AIMP/N otrzymało 5 CKiK - w Lublinie, Poznaniu, Warszawie i po jednym w Łodzi i Wrocławiu (ogólem 211). Koncentraty krwinek płytkowych przygotowano od 35 dawców (głównie HPA-1a ujemnych), wybranych $z$ rejestru dawców o oznaczonych antygenach HPA. Nie zawierały one antygenu, do którego były skierowane przeciwciała matki. Takie KKP są skuteczne klinicznie i zalecane dla noworodków z AIMPN. Pozostałe 176 KKP dla noworodków $z$ AIMPN przygotowano od dawców przypadkowych. W przypadkach niedostępności dawców dobranych w HPA, przetoczenie takich KKP jest dopuszczalne, wiadomo jednak, że płytki od takich dawców mają mniejszą skuteczność kliniczną $[18,19]$. Należy podkreślić, że $98 \%$ osób w populacji kaukaskiej ma antygen HPA-1a, co sprawia, że praktycznie nie ma szans, by KKP od dawcy przypadkowego nie zawierał tego antygenu, który najczęściej odpowiada za alloimmunizację kobiet w ciąży i jest główną przyczyną AIMPN.

W świetle obserwacji poczynionych przez IHiT można się spodziewać w Polsce wzrostu zapotrzebowania na KKP dla noworodków z AIMPN. Jest to spowodowane między innymi przeprowadzeniem szerokich badań przeglądowych antygenu HPA-1a, obejmujących teren całej Polski w ramach grantu PREVFNAIT finansowanego $z$ funduszy norweskich [11]. W badaniach tych zidentyfikowano ponad 600 kobiet $\mathrm{w}$ wieku rozrodczym, które są HPA-1a ujemne (2,4\% badanej grupy) i potencjalnie zagrożone konfliktem płytkowym w każdej ciąży (ryzyko immunizacji wynosi ok. 10\%). Biorąc pod uwagę roczną liczbę urodzeń, wynoszącą obecnie w Polsce około 403000 (2017 r.), 2,4-procentową częstość występowania fenotypu HPA-1a ujemnego w naszej populacji (jeśli u wszystkich kobiet w ciąży badano by antygen HPA-1a) oraz 10-procentowe ryzyko wytworzenia przeciwciał anty-HPA-1a, to można się spodziewać, że docelowo co roku dla okoto 960 zimmunizowanych kobiet HPA-1a ujemnych powinno zabezpieczyć się HPA-1a ujemne KKP na wypadek leczenia noworodka $z$ małopłytkowością. Najlepiej by były one, podobnie jak w Wielkiej Brytanii, stale dostępne [18]. Liczba dawców HPA-1a ujemnych dostępnych w każdym CKiK, zaopatrujących w KKP oddziały neonatologiczne, powinna być więc znacznie większa niż obecnie (133 dawców pochodzi jedynie z $7 \mathrm{CKiK}$ ). Są regiony Polski niedysponujące takimi dawcami.

Dodatkowo w ostatnich latach zwiększyła się dostępność diagnostyki konfliktu płytkowego, co zwiększa możliwości leczenia płodów/noworodków $z$ podejrzeniem AIMPN, w tym leczenia przetoczeniami KKP. Badania diagnostyczne wykonuje obecnie nie tylko IHiT, ale też CKiK w Białymstoku, Kaliszu, Katowicach, Lublinie i Opolu, które to ośrodki biorą udział w programie kontroli jakości wykrywania przeciwciał anty-HPA, organizowanych przez IHiT. Zwiększa się zatem możliwość wykrywania nie tylko przypadków AIMPN z przeciwciałami anty-HPA-1a, ale te $\dot{z}$ anty-HPA-5b i o innych swoistościach.

Dokonały się też zmiany w zakresie leczenia i opieki nad noworodkiem $z$ AIMPN. Leczeniem konfliktu płytkowego zajmują się obecnie nie tylko kliniki warszawskie, ale także ośrodki w Lublinie, Wrocławiu, Kielcach, Łodzi i Poznaniu.

Pion krwiodawstwa jest zobowiązany do zabezpieczenia dostępności dawców do przetoczeń dla noworodków z AIMPN i powiadomienia o tej dostępności referencyjnych ośrodków ginekologiczno-położniczych na terenie kraju.

$Z$ przeprowadzonej na rzecz obecnego opracowania analizy wynika, że od strony merytorycznej i organizacyjnej ośrodki polskiej służby krwi - CKiK i IHiT - są przygotowane do podjęcia zadania utworzenia ogólnopolskiego rejestru dawców o określonych antygenach HPA dla biorców zimmunizowanych, o wystarczająco wysokiej liczebności, by zapewnić bezpieczeństwo przetoczeń KKP dla tych pacjentów. Badania takie muszą być wykonywane sukcesywnie w miarę dostępnych środków. Konieczne jest zapewnienie niezbędnej aparatury oraz finansowanie kosztów badań.

\section{Perspektywiczne plany rozszerzenia rejestrów dawców o oznaczonych antygenach HPA dla pacjentów uodpornionych}

Badania muszą być prowadzone w trzech kierunkach:

1. Oznaczanie antygenu HPA-1a u dawców wielokrotnych w celu wytypowania dawców HPA1a ujemnych, stanowiących $\sim 2 \%$ dawców. Dysponowanie dawcami HPA-1a ujemnymi jest kluczowe. 
2. Wykonanie genotypowania $z$ kolejno pobranej próbki u dawców HPA-1a ujemnych w celu potwierdzenia genotypu $H P A-1 b / b$ (konieczne dla użycia ich płytek do przetoczeń dla noworodków) i oznaczenia u tych dawców antygenów $z$ innych układów HPA w celu identyfikacji homozygot, przede wszystkim $H P A-3 a / a$, $H P A-3 b / b, H P A-5 a / a$.

3. Wykonanie genotypowania $\mathrm{w}$ grupie dawców HPA-1a dodatnich w celu identyfikacji dawców KKP homozygotycznych pod względem antygenów HPA-1a, $-2 \mathrm{a},-2 \mathrm{~b},-3 \mathrm{a},-3 \mathrm{~b},-5 \mathrm{a},-5 \mathrm{~b}, \mathrm{z}$ różną kombinacją antygenów, koniecznych do leczenia pacjentów immunizowanych, przede wszystkim $z$ przeciwciałami anty-HPA-5b (konieczni dawcy o genotypie $H P A-5 a / a$ ) i anty-HPA-1b (dawcy o genotypie $H P A-1 a / a$ ). W tej grupie będą potrzebne badania weryfikacyjne dla wyselekcjonowanych dawców homozytycznych pod względem antygenów $z$ kilku układów HPA.

\section{Podsumowanie}

Utworzenie rejestru dawców krwi o oznaczonych antygenach HPA dla pacjentów $z$ przeciwciałami anty-HPA, w tym noworodków z AIMP/N, powinno być traktowane priorytetowo, ze względu na grupę docelową (noworodki) dla tych przetoczeń. Wykonanie tego zadania jest możliwe i będzie kontynuacją współdziałania IHiT oraz CKiK, które od wielu lat czynią wysiłki dla zwiększenia wykrywalności AIMP/N, a tym samym zmniejszenia umieralności noworodków oraz skutków tej choroby — niepełnosprawności w wyniku wylewu do ośrodkowego układu nerwowego.

Instytut Hematologii i Transfuzjologii ma odpowiednie kompetencje do wykonywania badań antygenów HPA (serologicznych i genetycznych), a także koordynacji programu. Od wielu lat uczestniczy jako laboratorium referencyjne w Warsztatach Immunologii Płytek w ramach działań Międzynarodowego Towarzystwa Przetaczania Krwi (ISBT) oraz w programach zewnętrznej oceny jakości badań z zakresu immunologii płytek. Prowadzi także program oceny jakości badań przeciwciał przeciwpłytkowych, fenotypowania antygenu HPA1a oraz genotypowania antygenów HPA dla CKiK. Wszystkie CKiK zainteresowane prowadzeniem diagnostyki alloimmunizacji antygenami HPA wykrywaniem przeciwciał anty-HPA i typowaniem antygenów HPA - mają możność uczestniczyć w programie oceny jakości prowadzonej przez IHiT.

Program zwiększenia liczebności rejestru dawców o oznaczonych antygenach HPA wymaga finasowania na zakup niezbędnej aparatury i pokrycia kosztów badań bez względu na to, gdzie (CKiK czy IHiT) będą wykonywane badania.

W opinii IHiT wskazane jest, by badania przeglądowe w kierunku identyfikacji dawców HPA-1a ujemnych były wykonywane techniką serologiczną opartą na cytometrii przepływowej FACS w kilku ośrodkach w kraju, które dysponują odpowiednią aparaturą. Należy do nich kilka CKiK oraz IHiT. Dodatkowo należy rozważyć stosowanie opracowanego ostatnio systemu badań antygenu HPA-1a i -5b technologią EVA [29]. Proponowana skala badań przeglądowych powinna objąć co najmniej 20000 dawców krwi, głównie grupy $\mathrm{O} \mathrm{RhD}$ ujemnej dla leczenia noworodków (np. 10 000), a dla innych pacjentów w podobnych proporcjach grupy $\mathrm{O}$ i A oraz proporcjonalnie do rozkładu w populacji grupy $\mathrm{B}$ i AB.

Dalsze badania potwierdzające u dawców HPA1a ujemnych genotyp $H P A-1 b / b$ wraz $z$ typowaniem innych układów HPA oraz badania dawców HPA-1a dodatnich, zmierzające do zidentyfikowania dawców homozygotycznych w innych układach HPA, powinny być zcentralizowane ze względów ekonomicznych. Tego zadania może podjąć się IHiT. Wykonanie genotypowania $z$ kolejno pobranej próbki u dawców HPA-1a ujemnych w celu potwierdzenia genotypu $H P A-1 b / b$ oraz oznaczenie antygenów $z$ innych układów HPA jest dostępne w Pracowni Genetyki Komórek Krwi i Chimeryzmu (PGKK) Zakładu Immunologii Hematologicznej i Transfuzjologicznej IHiT już w chwili obecnej. Podjęcie zadania badań przesiewowych u co najmniej 10000 dawców HPA-1a dodatnich, by zidentyfikować dawców $H P A-2 b / b, H P A-5 b / b$, wymaga inwestycji w infrastrukturę i personel.

\section{Podziękowania}

Autorzy dziękują PT Dyrektorom oraz Pracownikom CKiK za udostępnienie danych zawartych $\mathrm{w}$ ankiecie. Obecne opracowanie i złożony na początku 2017 roku raport do NCK zostały przygotowane w ramach dotacji na działalność publicznej służby krwi (Art. 25 Ustawy z dn. 22 sierpnia 1997 r. o publicznej stuzbie krwi).

\section{Piśmiennictwo}

1. Kaufman RM, Djulbegovic B, Gernsheimer T, et al. AABB. Platelet transfusion: a clinical practice guideline from the AABB. Ann Intern Med. 2015; 162(3): 205-213, doi: 10.7326/M14-1589, indexed in Pubmed: 25383671.

2. Klein HG, Anstee DJ. Immunology of leucocytes, plateletes and plasma components. W: Mollison's blood transfusion in clinical me- 
dicine. 12th Edition. Jphn Woley \& Sons Ltd Oxford UK 2014; 549-610.

3. Kumar A, Mhaskar R, Grossman BJ, et al. AABB Platelet Transfusion Guidelines Panel. Platelet transfusion: a systematic review of the clinical evidence. Transfusion. 2015; 55(5): 1116-1127; quiz 1115, doi: 10.1111/trf.12943, indexed in Pubmed: 25387589.

4. Maślanka K, Łopacz P, Łętowska M. Zasady przetaczania koncentratów krwinek płytkowych. Robak T, Warzocha K, (red). Hematologia. Via Medica. Gdańsk 2016; 281-292.

5. Kakaiya RM, Triulzi DJ, Wright DJ, et al. National Heart, Lung, and Blood Institute (NHLBI) Retrovirus Epidemiology Donor Study-II. Prevalence of HLA antibodies in remotely transfused or alloexposed volunteer blood donors. Transfusion. 2010; 50(6): 1328-1334, doi: 10.1111/j.1537-2995.2009.02556.x, indexed in Pubmed: 20070615.

6. Maślanka K. Współczesne poglądy na występowanie oporności na przetaczanie koncentratów krwinek płytkowych. Acta Haematol Pol. 2011; 42: 453-485.

7. Maślanka K, Uhrynowska M, Apel D, et al. Przydatność prób zgodności z użyciem limfocytów/płytek krwi w przewidywaniu skuteczności przetoczeń koncentratów krwinek płytkowych u chorych zimmunizowanych. Acta Haematol Pol. 2004; 35: 71-78.

8. Forest SK, Hod EA. Management of the Platelet Refractory Patient. Hematol Oncol Clin North Am. 2016; 30(3): 665-677, doi: 10.1016/j.hoc.2016.01.008, indexed in Pubmed: 27113003.

9. Kiefel V, Santoso S, Weisheit M, et al. Monoclonal antibody-specific immobilization of platelet antigens (MAIPA): a new tool for the identification of platelet-reactive antibodies. Blood. 1987; 70(6): 1722-1726, indexed in Pubmed: 2445398.

10. Maślanka K, Guz K, Uhrynowska M, et al. Rejestr dawców z oznaczonymi swoistymi antygenami płytek krwi (HPA) i jego zastosowanie w transfuzjologii. Acta Haematol Pol. 2005; 36: 189-196.

11. Uhrynowska M, Niznikowska-Marks M, Zupańska B. Neonatal and maternal thrombocytopenia: incidence and immune background. Eur J Haematol. 2000; 64(1): 42-46, indexed in Pubmed: 10680704.

12. Kamphuis MM, Tiller H, van den Akker ES, et al. Fetal and Neonatal Alloimmune Thrombocytopenia: Management and Outcome of a Large International Retrospective Cohort. Fetal Diagn Ther. 2017; 41(4): 251-257, doi: 10.1159/000448753, indexed in Pubmed: 27728915.

13. Uhrynowska ME, Dębska M, Guz K, et al. [PREVFNAIT prevention of foetal/neonatal alloimmune thrombocytopenia (FNAIT) in Polish foetuses and newborns--the PREVFNAIT program]. Ginekol Pol. 2015; 86(1): 62-66, indexed in Pubmed: 25775877.

14. Brojer E, Husebekk A, Dębska M, et al. Fetal/Neonatal Alloimmune Thrombocytopenia: Pathogenesis, Diagnostics and Prevention. Arch Immunol Ther Exp (Warsz). 2016; 64(4): 279-290, doi: 10.1007/s00005-015-0371-9, indexed in Pubmed: 26564154.

15. Guz K, Uhrynowska M, Kopeć I, et al. Recent advances in understanding the clinical relevance of antiplatelet alloantibodies. Pol Arch Intern Med. 2017; 127(3): 190-194, doi: 10.20452/ pamw.3932, indexed in Pubmed: 28377559.

16. Dębska M, Uhrynowska M, Guz K, et al. Identification and follow-up of pregnant women with platelet-type human platelet antigen (HPA)-1bb alloimmunized with fetal HPA-1a. Arch Med
Sci. 2018; 14(5): 1041-1047, doi: 10.5114/aoms.2016.63600, indexed in Pubmed: 30154886.

17. Żupańska B, Maślanka K, Michur H, et al. Jaką strategię należy zastosować, aby zwiększyć rozpoznawanie alloimmunologicznej małopłytkowości płodów i noworodków? Ginekologia po dyplomie. 2008; 4: 62-64.

18. Allen D, Verjee $\mathrm{S}$, Rees $\mathrm{S}$, et al. Platelet transfusion in neonatal alloimmune thrombocytopenia. Blood. 2007; 109(1): 388-389, doi: 10.1182/blood-2006-05-026419, indexed in Pubmed: 17190858.

19. Kiefel V. Antigen-positive platelet transfusion in neonatal alloimmune thrombocytopenia (NAIT). Blood. 2006; 107(9): 3761-3763, doi: 10.1182/blood-2005-06-2235.

20. Lucas GF, Bendukidize N. HPA-1a(-), 5b(-) platelets for use in neonatal alloimmune thrombocytopenia-from 'Cinderella' product to standard component. Transfus Med. 2014; 24(2): 127-129, doi: 10.1111/tme.12108, indexed in Pubmed: 24684573.

21. Allen DL, Samol J, Benjamin S, et al. Survey of the use and clinical effectiveness of HPA-1a/5b-negative platelet concentrates in proven or suspected platelet alloimmunization. Transfus Med. 2004; 14(6): 409-417, doi: 10.1111/j.1365-3148.2004.00536.x, indexed in Pubmed: 15569235.

22. Kamphuis MM, Paridaans NP, Porcelijn L, et al. Incidence and consequences of neonatal alloimmune thrombocytopenia: a systematic review. Pediatrics. 2014; 133(4): 715-721, doi: 10.1542/ peds.2013-3320, indexed in Pubmed: 24590747.

23. Maslanka K, Guz K, Zupanska B. Antenatal screening of unselected pregnant women for HPA-1a antigen, antibody and alloimmune thrombocytopenia. Vox Sang. 2003; 85(4): 326-327, indexed in Pubmed: 14633260.

24. Wróbel A, Guz K, Orzińska A, et al. Automatyzacja przesiewowego fenotypowania antygenu HPA-1a u kobiet ciężarnych - doświadczenia własne. Acta Haematologica Polonica. 2015; 46: 20-21, doi: 10.1016/j.achaem.2015.07.039.

25. Skogen B, Bellissimo DB, Hessner MJ, et al. Rapid determination of platelet alloantigen genotypes by polymerase chain reaction using allele-specific primers. Transfusion. 1994; 34(11): 955-960, indexed in Pubmed: 7526491.

26. Ficko T, Galvani V, Rupreht R, et al. Real-time PCR genotyping of human platelet alloantigens HPA-1, HPA-2, HPA-3 and HPA- 5 is superior to the standard PCR-SSP method. Transfus Med. 2004; 14(6): 425-432, doi: 10.1111/j.1365-3148.2004.00538.x, indexed in Pubmed: 15569237.

27. Guz K, Krzemienowska M, Orzińska A, et al. Polimorfizm $+24 \mathrm{G}>$ del $\mathrm{w} 3$ intronie genu ITGB3 $\mathrm{w}$ regionie diagnostycznym genotypowania allelu HPA-1a: konsekwencje i metody weryfikacji. J Transfus Med. 2013; 6(2): 33-40.

28. Pavenski K, Freedman J, Semple JW. HLA alloimmunization against platelet transfusions: pathophysiology, significance, prevention and management. Tissue Antigens. 2012; 79(4): 237-245, doi: 10.1111/j.1399-0039.2012.01852.x, indexed in Pubmed: 22385314.

29. Merieux Y, Schwab C, Saint-Cyr M, et al. Evaluation of Diagnostic Tests by Evanescence Biosensor Technology for Rapid Phenotyping of the Human Platelet Alloantigens 1a and 5b. Transfusion Medicine and Hemotherapy. 2018, doi: $10.1159 / 000493556$. 